Original Research Paper

\title{
Mechanical Properties of Concrete Including Wood Shavings as Fine Aggregates
}

\author{
${ }^{1}$ Ashraf A. M. Fadiel and ${ }^{2}$ Taher Abu-Lebdeh \\ ${ }^{1}$ Department of Civil Engineering, Omar Al-Mukhtar University, El-Bieda, Libya, P.O.Box 919, Libya \\ ${ }^{2}$ Department of Civil, Architectural and Environmental Engineering, \\ North Carolina A and T State University, NC 27411 Greensboro, USA
}

\section{Article history}

Received: 29-11-2021

Revised: 08-12-2021

Accepted: 13-12-2021

Corresponding Author:

Taher M. Abu-Lebdeh

Department of Civil,

Architectural and

Environmental Engineering,

North Carolina A and T State

University, NC 27411

Greensboro, USA

Email: taher@ncat.edu

\begin{abstract}
Residual and end-life products are a major hazard on the environment. Many researchers have considered waste as partial replacement of some construction materials to reduce their environmental and ecological problems. This kind of practices can be an important option for the protection of the environment. Wood shavings and saw dust are byproduct of the lumber industry. They are made from timber that's been sawn into planks in saw mills in almost every major city worldwide. This is a daily activity that generates piles of wood residuals at the end of each day. This research investigates the effect of using wood shavings on the mechanical properties of concrete. Fine aggregate was replaced by volume at different levels of replacement by wood shavings. Five different levels of replacement were used, namely 5, 10, 15, 30 and 50\% and the results were compared to conventional concrete. Tests were carried out on concrete in fresh and hardened phase to determine slump, wet unit weight, compressive strength, splitting tensile strength, flexural strength, dry unit weight and absorption. The results showed that up to $10 \%$ level of substitution, the concrete maintained acceptable mechanical properties in comparison to conventional concrete.
\end{abstract}

Keywords: Saw Dust, Wood Shavings, Wood Crete, Fine Aggregate, Compressive Strength, Lightweight Materials

\section{Introduction}

The cost of building materials such as cement, granite, sand and coarse aggregates is constantly growing. Other low-cost materials, such as wastes and byproducts, are being investigated by researchers. Recycling waste into new construction materials could be a practical solution not only to the pollution problems, but also to the problem of high-cost construction materials.

In the last few years, end use and by-products have become focus for researchers and environmentalists due their negative impact on the environment and they usually generate complicated problems. Utilizing end use and by-products in engineering applications have become highly appreciated practice. Many researchers have investigated end used and by-products materials and have arrived to encouraging conclusions. Recycling of waste materials is been considered as feasible solution to save natural resources, save energy, reduce solid waste, decrease air and water pollutants and reduce greenhouse gases (Bolden et al., 2013; Abu-Lebdeh et al., 2014; Fadiel et al., 2014; Ashraf, 2015; Fadiel, 2013; Adesanya and Raheem, 2009).
Several studies have considered using waste materials and end-life products as partial replacement of conventional construction materials as an effort to find a sustainable, sensible and environmentally sound solution. Several authors considered using crumb rubber generated from scrap and used tires in concrete (Abu-Lebdeh et al., 2014; Fadiel et al., 2014; Ashraf, 2015). (Fadiel, 2013; Fadiel et al., 2014) studied the effect of crumb rubber on the thermal conductivity of cement-based materials and gypsum. They found that, by adding crumb rubber into mortar and gypsum, thermal conductivity of rubberized mortar was reduced by about $28 \%$ compared to conventional mortar and by $38 \%$ compared to ordinary gypsum.

Saw dust and wood shavings are waste products produced by the wood-based industries. They develop as little irregular chips or small debris of wood during the cutting of timber logs into various shapes and sizes. The proportions of saw dust and wood shavings are determined by the kind of wood and the size of the saw teeth. Every year, a significant quantity of saw dust is produced throughout the world. The dumping of timber industry byproducts on landfills negatively impacts the ecosystem. 
According to United States Environmental Protection Agency (EPA), In 2018, wood waste equaled about $6.2 \%$ of total Municipal Solid Waste (MSW) with total of 18,090 thousand of U.S. tons. landfills received about $67 \%$ of total generated waste wood, only $17 \%$ of that amount was recycled (USEPA, 2021). Study done by (Daian and Ozarska, 2009) reported that in Australia, around 7 to $40-50 \%$ of the yearly supply of wooden raw material becomes leftovers throughout the operation of wood-related businesses. Saw dusts and shavings account for approximately 65-85 percent of the entire quantity of waste wood by weight. The expenditures incurred in purchasing the raw material, which is eventually disposed of or given away, are estimated to account for 85-95 percent of the real cost of wood waste.

Materials made of wood fibers, have good sound absorption and thermal conductivity close to that of expanded polystyrene and glass wood (Bederina et al. 2007; Koohestani et al., 2016; Li et al., 2017).Wood shavings are now employed in the production of cement-based goods such as cement bound particle board. The compatibility of wood and cement has stimulated the interest of academics, who are looking into its usage as a partial substitute for sand in concrete mixes (Bołtryk and Pawluczuk, 2014). Another significant advantage of employing wood byproducts is their low cost, availability in big quantities and ease of processing. Researchers agree that saw dust may be used as a source of energy or as a raw material in the production of particle board, fine board and other products (Siddique et al., 2020).

The work present herein is aimed to provide more understanding to the mechanical behavior of woodcrete (concrete contain wood shavings) and find an optimum replacement ratio of wood shavings to be used in concrete without compromising its mechanical properties hence promote their use as possible construction material.

\section{Experimental Program}

An extensive experimental program was established to examine the effect amount of wood shavings on the properties of concrete. Control mixture was designed based on American Concrete Institute ACI 211.

At the hardened phase different sizes of specimens were prepared according to ASTM C192, to test compressive strength, splitting tensile strength and flexural strength. also, dry unit weight and absorption were tested at this phase. In addition, during the fresh phase of concrete the slump, wet unit weight were evaluated according to relative ASTM standards.

\section{Materials}

\section{Cement}

Portland cement type I ( $42.5 \mathrm{~N})$ with specific gravity of 3.11 was used in this research, the physical and mechanical properties of the cement are listed in Table 1. The cement met the standard requirements of ASTM C150-12.
Table 1: Physical and Mechanical properties of cement

\begin{tabular}{lll}
\hline Property & Value & Standard \\
\hline Initial setting time, $(\mathrm{min})$ & 115 & $>45$ \\
Final setting time, $(\mathrm{min})$ & 220 & $<600$ \\
Soundness, $(\mathrm{mm})$ & 2 & $<10$ \\
Specific Surface Area, $\left(\mathrm{m}^{2} / \mathrm{Kg}\right)$ & 312 & minimum 260 \\
Compressive strength, $(\mathrm{MPa})$ & 3 days $=17$ & $12 \mathrm{MPa}$ \\
& 7 days $=30.5$ & $19 \mathrm{MPa}$ \\
\hline
\end{tabular}

Table 2: Sieve analysis of coarse aggregate

\begin{tabular}{lllllll}
\hline Sieve size (mm) & 38.1 & 19 & 12.5 & 9.5 & 4.75 & 2.36 \\
\hline Passing (\%) & 100 & 93.64 & 47.05 & 21.78 & 0.99 & 0.23 \\
Standards & 100 & $90-100$ & ---- & $20-55$ & $0-10$ & $0-5$
\end{tabular}

Wood Shavings (WS)

\section{Sand}

Gradation of sand used in this study conformed to the ASTM C33 standards. specific gravity and absorption for sand was tested according to ASTM C128 and found to be 2.67 and $0.3 \%$ respectively. Sand has bulk density of $1767 \mathrm{~kg} / \mathrm{m}^{3}$.

\section{Coarse Aggregate}

Gradation of Coarse aggregate used in this research conformed to the ASTM C33 standards (Table 2). specific gravity and absorption for coarse aggregate was tested according to ASTMC127 and it found to be 2.59 and $1.4 \%$ respectively. Coarse aggregate has Fineness Modulus (FM) of 7.36 and bulk density of $1534 \mathrm{~kg} / \mathrm{m}^{3}$. coarse aggregate has impact and crushing values of 16.4 and $24 \%$ respectively.

Wood shavings with particle size ranged from 0.15 to $4.75 \mathrm{~mm}$ used in this study (Fig. 1). Gradation of WS and sand are presented in Fig. 2. WS has a specific gravity and absorption of 1.18 and $19 \%$ respectively. WS has fineness modulus of 2.79 . WS has a loose density of $244 \mathrm{~kg} / \mathrm{m}^{3}$ and bulk density of $465 \mathrm{~kg} / \mathrm{m}^{3}$. The wood shavings was used in saturated surface dry condition throughout the course of the study, also, it showed be mentioned that wood shavings did not exposed to any type of chemical treatment. It was noted that with saturated wood shavings would disperse better in the dry mixture and will not absorb the free water which is intended to hydrate of cement and maintain acceptable workability of concrete (Bederina et al., 2007).

\section{Mix Proportioning and Casting}

Concrete mix was designed based on (The American institute of concrete) Table 3 shows the research plan and mix proportions of each concrete mix. In addition to the control mix (concrete without WS), five levels of replacement of wood shavings by volume of fine aggregate were used. Namely, 5, 10, 15, 30 and 50\%. Mix contain 5\% of WS was labeled as 5\% WS and so on. ASTM standards were followed to determine fresh and hardened properties of mixtures. workability, unite weight, compressive strength, split tensile strength, flexural strength and absorption. The 
sizes of testing specimens used in this research were: $(100 \times$ $100 \times 100 \mathrm{~mm})$ cubes, $(100 \times 200 \mathrm{~mm})$ cylinders and $(100 \times$ $100 \times 500 \mathrm{~mm}$ ) beams. A total of 36 cubes, 36 cylinders and 36 beams were prepared and tested for ages of 7 and 28 days. All mixtures were mixed in a laboratory pan mixer with a volume capacity of $0.056 \mathrm{~m}^{3}$. Cement, Fine aggregate, coarse aggregate and wood shavings were first mixed for 1-2 min in dry condition. After homogenous distribution was achieved, water was added gradually and mixed for extra 2 min. After confirming that the mix was workable, the mix was poured into the molds and vibrated on a vibrating table. Then excess mix was removed and the specimen's surface was finished with a steel trowel. The specimens were covered with plastic bags for $24 \mathrm{~h}$ to maintain humidity. After that, the specimens were de-molded and placed in the cure tank up to the age of test (Fig. 3).

Table 3: Mix ID and mix proportions for cubic meter

\begin{tabular}{|c|c|c|c|c|c|c|}
\hline & Cement & Sand & $\begin{array}{l}\text { Weight }(\mathrm{kg}) \text { per } \mathrm{m}^{3} \\
\text { Coarse Aggregate }\end{array}$ & WS & water & $\begin{array}{l}\text { W/C } \\
\text { Ratio }\end{array}$ \\
\hline $\mathrm{CM}$ & 418 & 671.2 & 1012.5 & 0 & 205 & 0.49 \\
\hline $5 \% \mathrm{WS}$ & 418 & 637.6 & 1012.5 & 14.8 & 205 & 0.49 \\
\hline $10 \% \mathrm{WS}$ & 418 & 604.1 & 1012.5 & 29.7 & 205 & 0.49 \\
\hline $15 \% \mathrm{WS}$ & 418 & 570.6 & 1012.5 & 44.5 & 205 & 0.49 \\
\hline $30 \% \mathrm{WS}$ & 418 & 469.9 & 1012.5 & 89.0 & 205 & 0.49 \\
\hline $50 \% \mathrm{WS}$ & 418 & 335.6 & 1012.5 & 148.3 & 205 & 0.49 \\
\hline
\end{tabular}

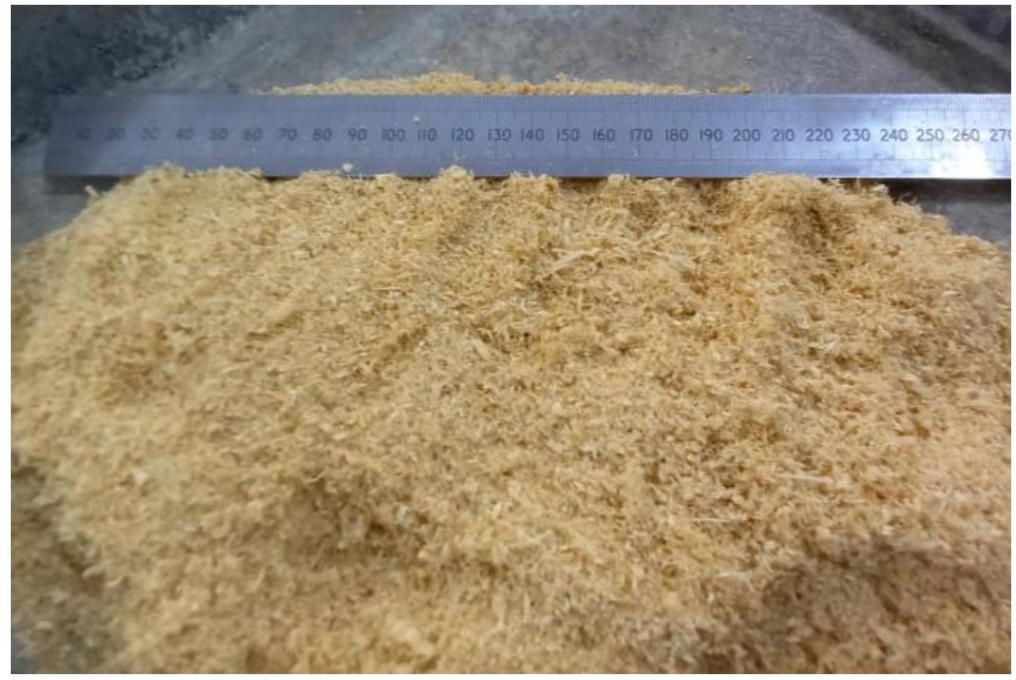

Fig. 1: Wood shavings

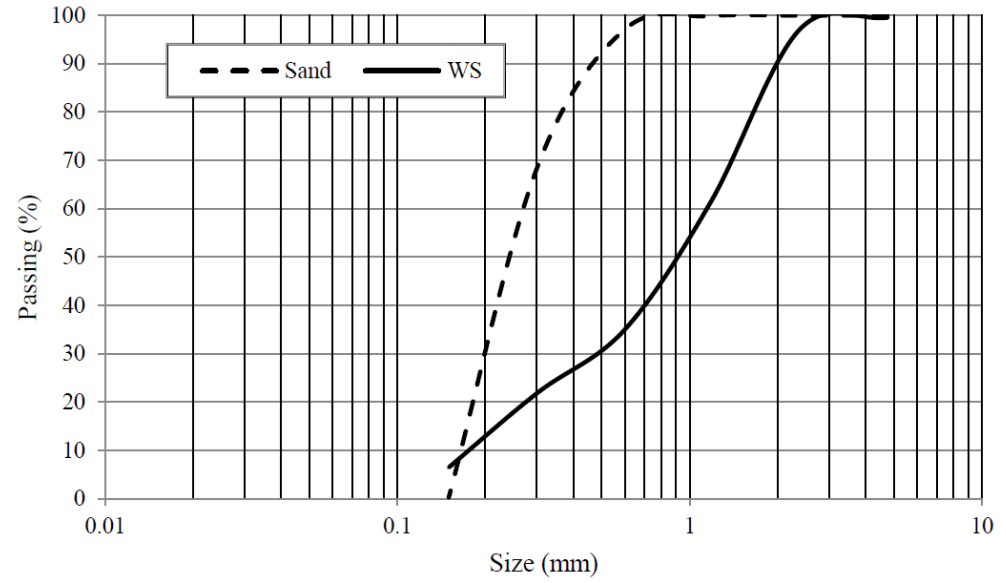

Fig. 2: Gradation of fine aggregate and wood shavings 

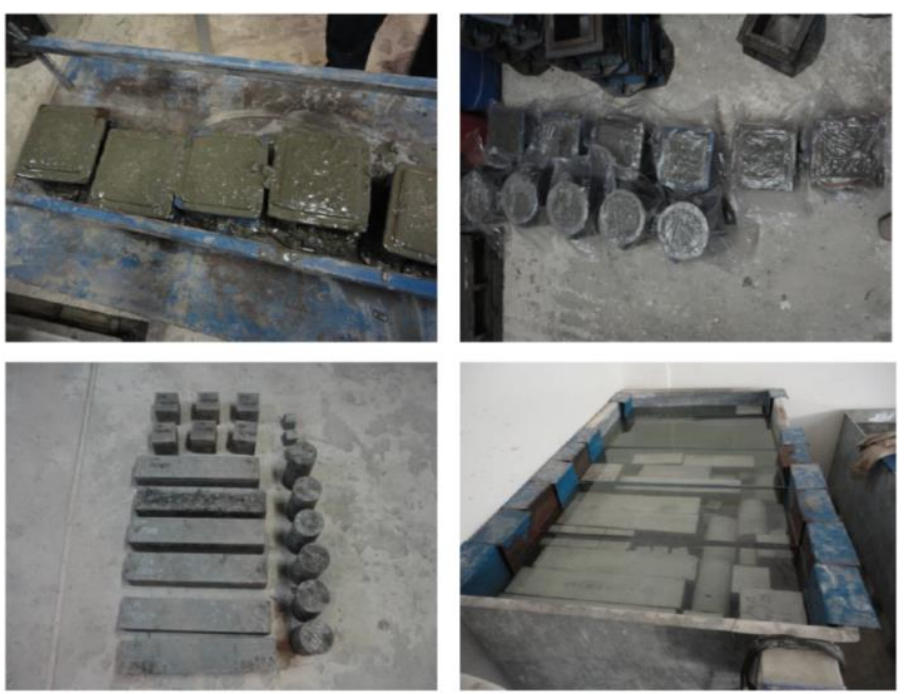

Fig. 3: Specimens

\section{Results and Discussion}

\section{Workability}

The workability of concrete mixtures were evaluated using slump test apparatus, the slump test was performed according to ASTM C143/C143M. The results of the slump, indicating the workability of the woodcrete are presented in Fig. 4. The slump values decrease as the WS content increases. The slump for concrete mixtures 5, 10, 15, 30 and 50\% WS were decreased by $30,37.5,70,71.5$ and $77.5 \%$ respectively compared to control mix which has slump of $200 \mathrm{~mm}$.

Reduction of the slump values indicates the reduction of the workability of concrete mixtures containing wood shavings. As the amount of wood shavings increased, the internal friction between individual partials in the concrete increased which cause to produce less workable mixtures.

\section{Wet Unit Weight}

Wet unit weight represent the density of fresh concrete. ASTM C138 was followed to determine the wet unit weight of all mixtures. Simply, wet unit weight is determined by weighing the compacted fresh concrete in standard container of known volume and mass. Figure 5 represents the wet unit weight values. The wet unit weight for concrete mixtures 5 , $10,15,30$ and $50 \%$ WS were reduced by $8.8,16.7,19.5,26.3$ and $37 \%$ respectively compared to control mix. The wet unit weight for wood Crete varied from 2211 to $1528 \mathrm{~kg} / \mathrm{m} 3$. It's obvious that the inclusion of wood shavings decreases the weight of concrete mixtures since the wood shavings has lower specific gravity than fine aggregate.

\section{Absorption}

ASTM C642-13, Fig. 6 demonstrate the effect of wood shavings particles on water absorption of concrete. It was observed that, the water absorption increased as the amount of wood shavings increased. The water absorption ratio of 5, 10, 15, 30 and 50\%WS were 9.0, 7.9, 9.8, 17.6 and $26.8 \%$ respectively. While the control mixture has absorption of $5.9 \%$. Logically, the increase of water absorption is due the ability of wood to absorb water, so with the increase of wood shavings content the absorption will increase. However, the absorption of all concrete mixtures containing wood shavings were less than $30 \%$. Consequently, the wood crete can be utilized in inner and outer walls in buildings (Li et al., 2017).

\section{Dry Unit Weight}

Dry unit weight is calculated according to ASTM C 642-13 and demonstrated in Fig. 7. The test results revealed that the dry unit weight was decreased as the amount of wood shavings increased and ranged from 1507 to $2234 \mathrm{~kg} / \mathrm{m}^{3}$, while the dry unit weight of control mix was about $2420 \mathrm{~kg} / \mathrm{m}^{3}$. The decrease in the dry unit weight is attributed to the lighter weight of WS compared to sand and also due the increase of air content in the mixtures contain WS. According to ACI 213 R-87 concrete with densities ranged between 300 to $1800 \mathrm{~kg} / \mathrm{m}^{3}$ and compressive strength ranged from 7 to $17 \mathrm{MPa}$ is considered as lightweight concrete. Concrete mixture with $30 \%$ of WS has a density of $1798 \mathrm{~kg} / \mathrm{m}^{3}$ and compressive strength of about $7.5 \mathrm{MPa}$, so it could be considered as lightweight concrete.

\section{Compressive Strength}

Compressive strength of concrete mixtures was determined according to BS 1881: Part 116: 1983. The average compressive strength of three specimens of each concrete mixture was allocated as the compressive strength of that concrete mix. Figure 8 demonstrates the compressive strength of concrete mixes containing different amounts of 
WS at ages of 7 and 28 days. At 7 days, concrete mixes 5, $10,15,30$ and $50 \%$ WS showed 39.2, 54.4, 67.2, 85.0 and $96.0 \%$ respectively lower compressive strength compared to control concrete. However, 5 and 10\% WS mixtures have compressive strength of 23 and $17.5 \mathrm{MPa}$ respectively. likewise, at 28 days, reduction in compressive strength was recorded. Concrete mixtures 5, 10, 15, 30 and 50\%WS, showed 32.3, 46.1, 67.3,84.6 and 95\% lower compressive strength in comparison to control concrete. However, mixtures containing 5 and $10 \%$ of wood shavings showed acceptable compressive strength which are 32 and 25.5 MPa. The linear regression analysis of data demonstrate the compressive strength decreased almost linear manner as the amount of wood shavings increased. The coefficient of determination $\left(\mathrm{R}^{2}\right)$ found to be 0.9 for the age of 7 days and 0.86 for the age of 28 days. The decrease of compressive strength can be attributed to poor bond between wood shavings particles and the surrounding cement paste, wood shavings particles are less stiff than sand and the water released from WS particles during mixing procedure increases the free water hence increases the actual w/c ratio.

The inclusion of wood shavings caused a degradation in the compressive strength (Usman et al., 2018), Siddique et al. (2020) and Bederina et al. (2009) reported similar observation. However, up to $10 \%$ level of replacement, the concrete mixtures exhibited acceptable compressive strength which can be considered for nonstructural elements. The effect of wood shavings on the compressive strength at higher percentage is more pronounced, however, at up to $10 \%$ level of replacement the existence of wood shavings does not have much effect on the interface between coarse aggregate and hydrated cement paste. In addition, the good quality of coarse aggregate use herein may have a great impact on the compressive strength and limited the degradation of the compressive strength of concrete mixtures containing wood shavings.

\section{Splitting Tensile Strength}

The split tensile strength was carried out according to ASTM C496. The average of three cylindrical specimens of each concrete mixture was assigned as the splitting tensile strength of that mix Fig. 9. The splitting strength was calculated based on the following equation:

$$
f_{t}=\frac{2_{P}}{\pi D L}
$$

Where:

$f_{t}$ : Splitting tensile strength (MPa) P: The failure load (KN).

$D$ : The diameter of the concrete cylinder $(\mathrm{mm})$.

$L$ : The height of the concrete cylinder ( $\mathrm{mm})$.

The split tensile strength decreased as the amount of wood shavings increased. Figure 10 Illustrates the average splitting tensile strength for different mixtures at ages of 7 and 28 days. At 7 days, concrete mixtures 5, 10, 15, 30 and $50 \%$ WS, showed $29.1,32.8,59.3,79.8$ and $92.1 \%$ reduction in splitting tensile strength compared to control concrete. likewise, at 28 days, the splitting tensile strength was decreased as the amount of wood shavings increased. The 5, $10,15,30$ and $50 \%$ WS mixes, showed 38.8, 35.3, 52.9, 76.8 and $91.2 \%$ lower splitting tensile strength than that of control concrete. The linear regression analysis of data demonstrate the splitting tensile strength decreased almost linearly with increase of wood shavings content. The coefficient of determination $\left(\mathrm{R}^{2}\right)$ found to be 0.91 at 7 days and 0.96 at 28 days. For concrete mixes containing 5 and $10 \%$ of wood shavings the development of splitting strength was higher at early testing age than later testing age. Other concrete mixtures showed lower rate of reduction at 28 days compared to control mix.

The typical failure modes of concrete cylinders were observed. Control mix experienced one failure along the line of the loading strip, control mix failed in brittle manner. On the other hand, wood crete showed a ductile failure mode. Figure 12, shows the failure modes of control mix and mixtures specimen contain $50 \%$ of wood shavings under split tensile load.

\section{Flexural Strength}

The flexural strength or (the modulus of rupture) was performed according to ASTM C78 (third point loading Fig. 11).

The average of three beam specimens of each concrete mixture was assigned as the flexural strength of that mixture. Table 4 and Fig. 12. show the flexural strength of mixtures containing WS particles at 7 and 28 days. Like the case of the compressive strength, the flexural strength of concrete was found to decrease proportionally with the increase of wood shavings content. At 7 days, concrete mixtures of 5, 10, 15, 30 and 50\% WS showed 23.9, 33.7, $39.1,70.7$ and $31.5 \%$ respectively lower flexural strength compared to control mix. Up to $30 \%$ level of replacement the flexural strength decreases with the increase of wood shavings content, however, the reduction in the flexural strength of $50 \% \mathrm{WS}$ concrete mixture was less than other concrete mixtures where the mix recorded $3.15 \mathrm{MPa}$. Similarly, at 28 days, reduction in flexural strength was recorded. The flexural strength of concrete mixtures of 5, 10, 15,30 and $50 \% \mathrm{WS}$, showed 42, 45.6, 51.2, 71.2 and $44 \%$ were less than control mixture. The $50 \%$ WS concrete mixture showed same trend, the mixture recorded a 3.5 $\mathrm{MPa}$ which is higher than the values obtained by mixes contain $(10-30 \%)$ of wood shavings. The reduction of flexural strength at age of 28 days was higher than that of 7 days age.

The lack of a conventional fine aggregate was directly resulted in the loss of flexural strength. The increase of flexural strength at $50 \%$ level of replacement can be attributed to the increase of wood shavings content which act like fibers in concrete mixture which leads to improve the 
capacity of energy absorption due the distributed stresses along the failure surface caused by wood shavings.

All woodcrete mixtures, have same failure pattern, where the line of fracture occur at the middle third of the specimens. Table 4 presents the average compressive strength, splitting tensile and flexural strength at ages of 7 and 28 days.

Table 4: Summary of mechanical properties of different concrete mixtures

\begin{tabular}{|c|c|c|c|c|c|c|}
\hline \multirow[b]{2}{*}{ Mixture ID } & \multicolumn{2}{|c|}{ Compressive strength (MPa) } & \multicolumn{2}{|c|}{ Splitting tensile strength (MPa) } & \multicolumn{2}{|c|}{ Flexural strength (MPa) } \\
\hline & 7 Days & 28 Days & 7 Days & 28 Days & 7 Days & 28 Days \\
\hline$\overline{\mathrm{CM}}$ & 38.1 & 47.1 & 3.4 & 4.1 & 4.6 & 6.3 \\
\hline $5 \% \mathrm{WS}$ & 23.1 & 31.9 & 2.1 & 2.9 & 3.5 & 3.6 \\
\hline $10 \% \mathrm{WS}$ & 17.4 & 25.4 & 2.2 & 2.7 & 3.1 & 3.4 \\
\hline $15 \% \mathrm{WS}$ & 12.5 & 15.4 & 1.6 & 1.7 & 2.8 & 3.1 \\
\hline $30 \% \mathrm{WS}$ & 5.7 & 7.3 & 0.8 & 0.8 & 1.4 & 1.8 \\
\hline $50 \% \mathrm{WS}$ & 1.5 & 2.4 & 0.3 & 0.3 & 3.2 & 3.5 \\
\hline
\end{tabular}

Table 5: Compressive strength and split tensile strength ratio

\begin{tabular}{lllllll}
\hline Age (day) & \multicolumn{2}{l}{ (Compressive strength/Split tensile strength) } & & & \\
& CM & $5 \% \mathrm{WS}$ & $10 \% \mathrm{WS}$ & $15 \% \mathrm{WS}$ & $30 \% \mathrm{WS}$ & $50 \% \mathrm{WS}$ \\
\hline 7 & 11.19 & 11.12 & 7.89 & 7.81 & 7.20 & 5.00 \\
28 & 11.63 & 11.11 & 9.34 & 9.33 & 8.84 & 7.34 \\
\hline
\end{tabular}

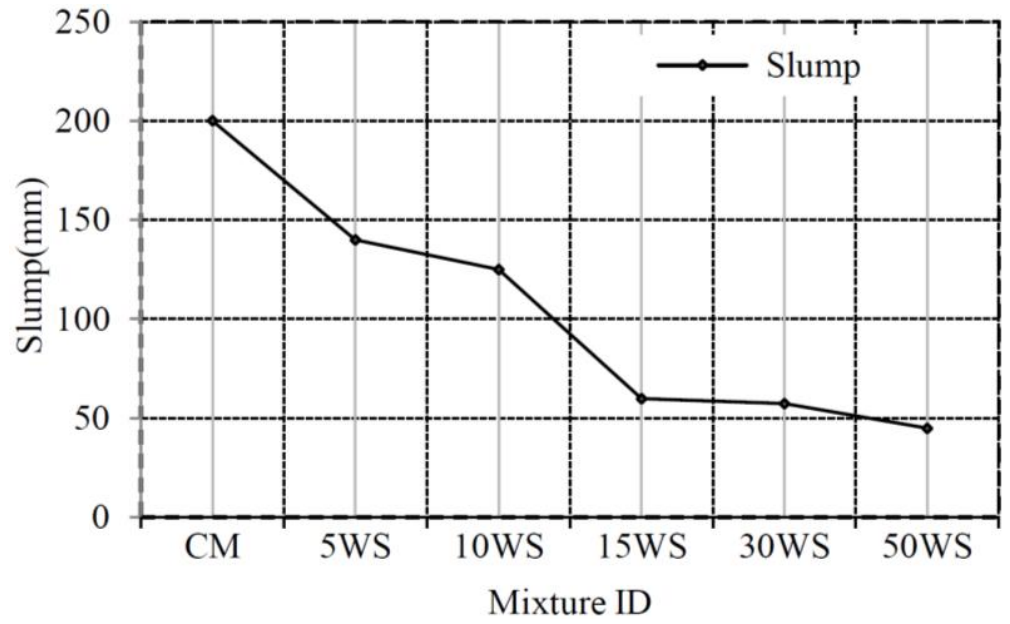

Fig. 4: Slump test values

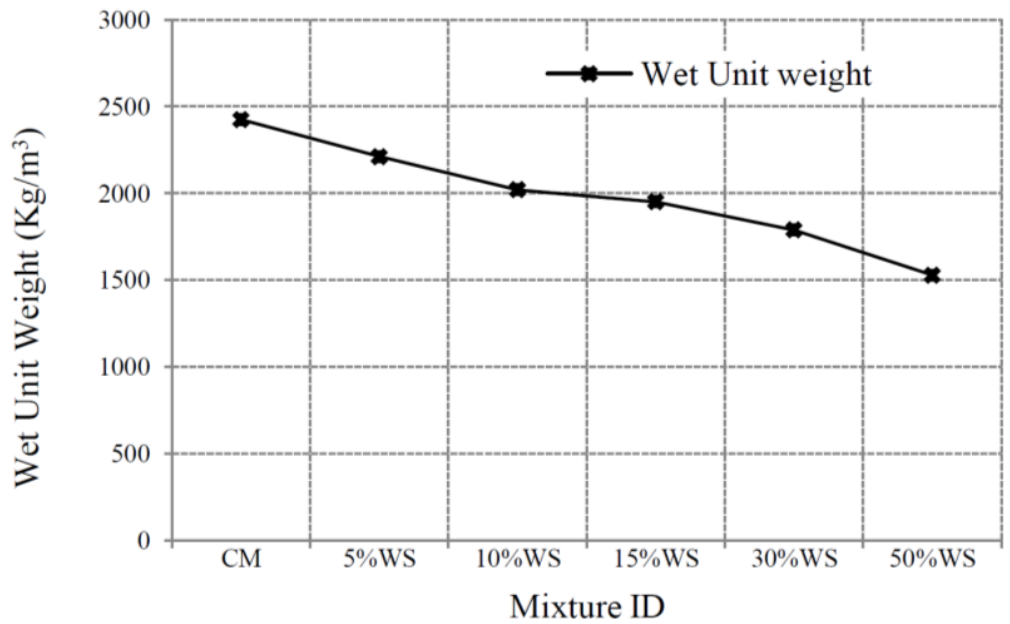

Fig. 5: Wet unit weight results 
Ashraf A. M. Fadiel and Taher Abu-Lebdeh / American Journal of Engineering and Applied Sciences 2021, 14 (4): 478.487 DOI: 10.3844/ajeassp.2021.478.487

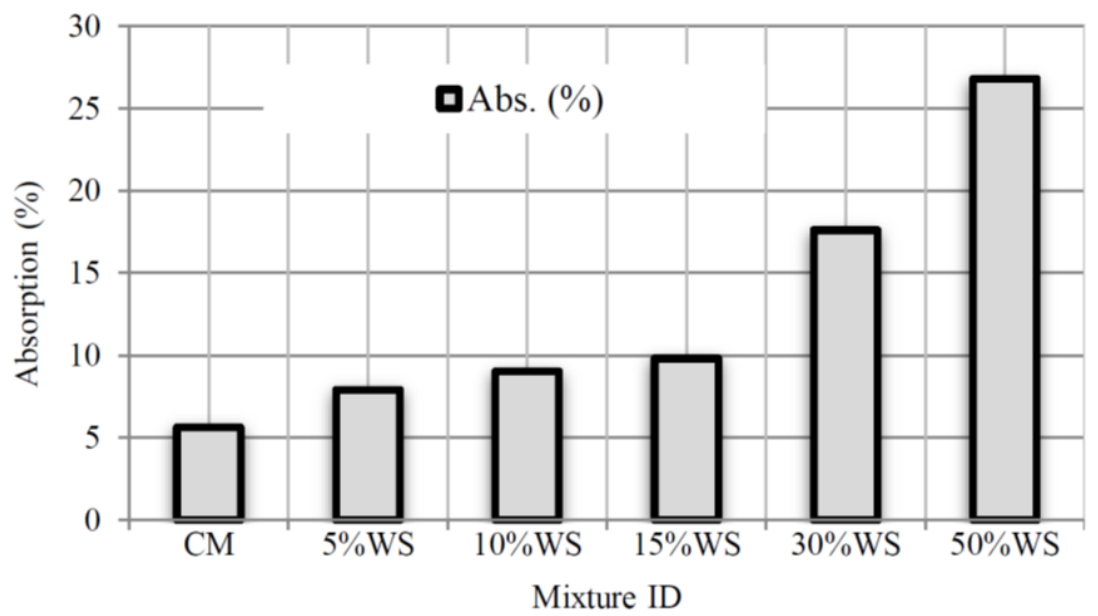

Fig. 6: Water absorption for varies concrete mixtures

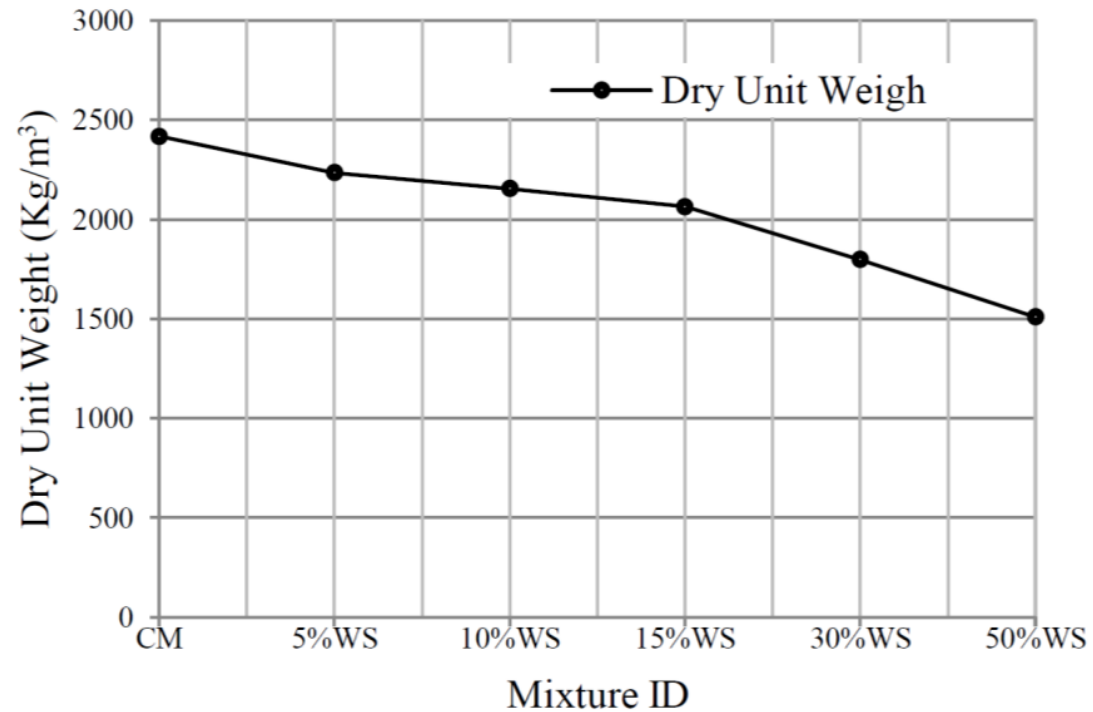

Fig. 7: Dry unit weight results

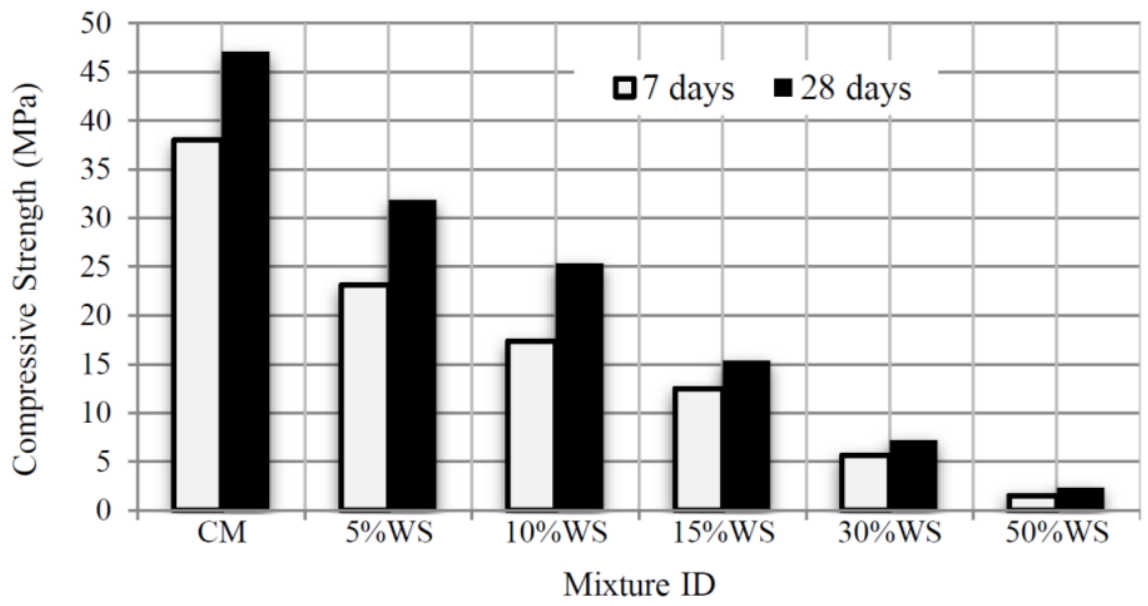

Fig. 8: Compressive strength of concrete incorporating WS 


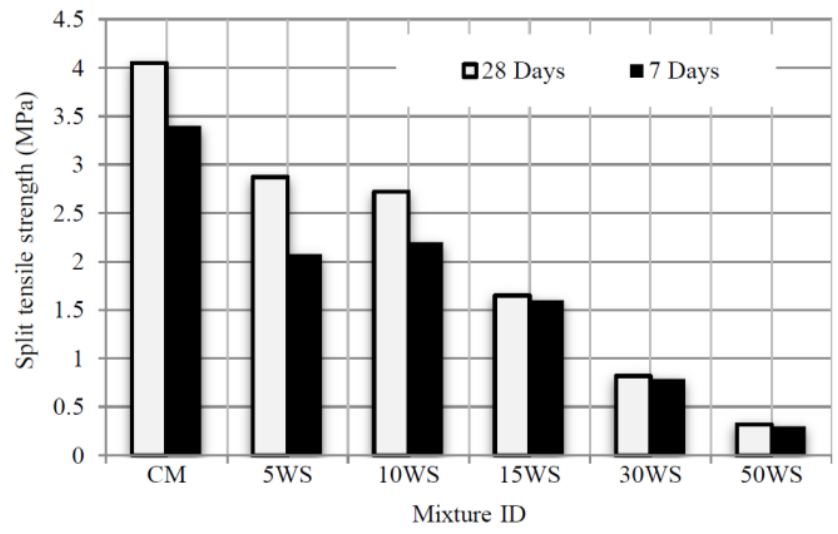

Fig. 9: Average splitting tensile strength of concrete mixtures incorporating wood shavings
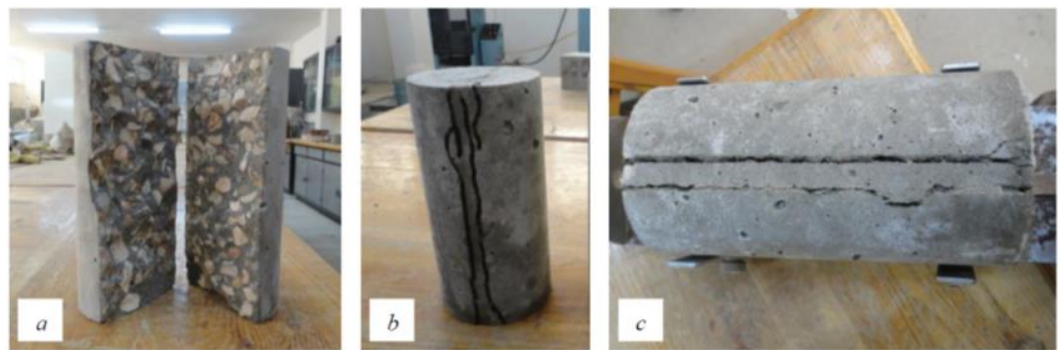

Fig. 10: Failure modes of splitting tensile strength for different mixes: (a) control mix, (b) $30 \%$ WS concrete mix and (c) $50 \%$ WS concrete mix

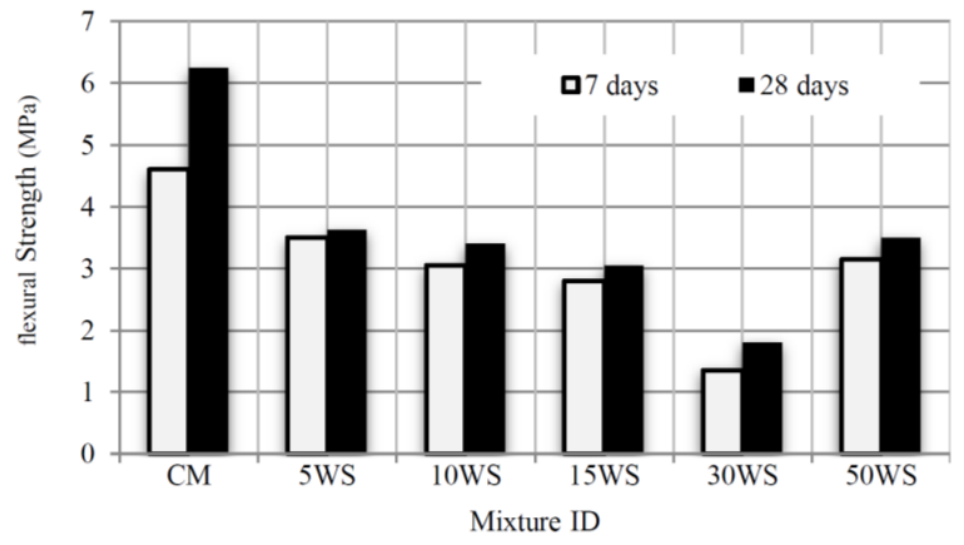

Fig. 11: Flexural strength of mixes incorporating wood shavings
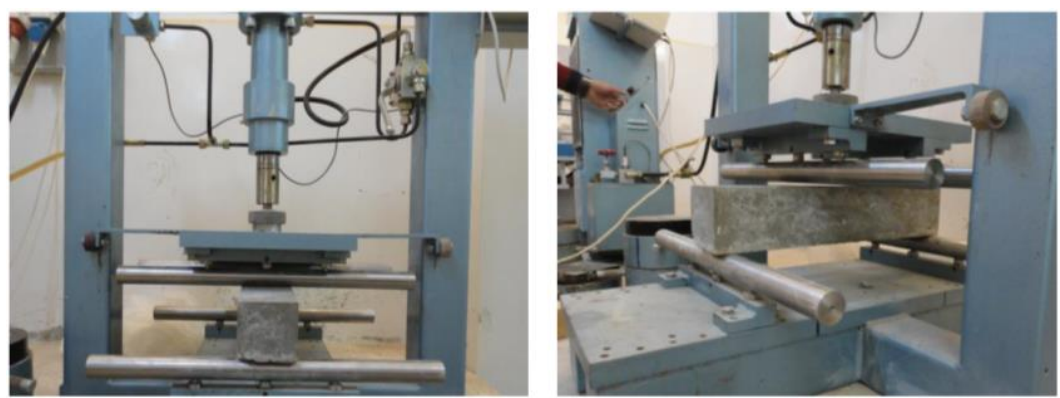

Fig. 12: Flexural test setup 


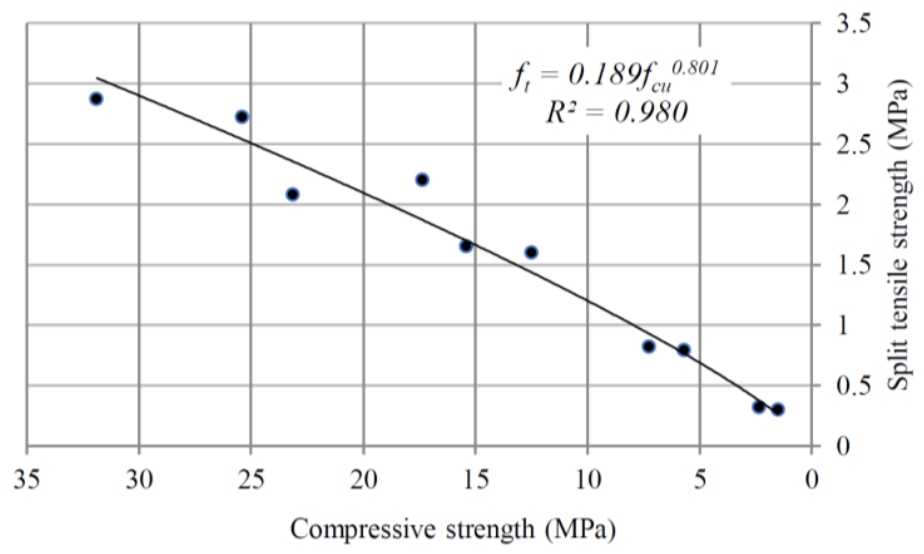

Fig. 13: Compressive strength and splitting tensile strength of concrete containing wood shavings

\section{Relation between Compressive Strength and Splitting Tensile Strength}

The ratio of compressive strength and splitting tensile strength of woodcrete and control mix are presented in Table 5. At all ages, the development of compressive strength and splitting tensile strength of wood crete is less than control mix, moreover, the compressive to splitting tensile strength ratio decreased as the amount of wood shavings increased. In addition, 50\% WS mixture showed lower compressive strength and splitting tensile strength ratio and this may be due to the resistance provided by wood shavings which acts as fissber in this stage causing improvement in the energy absorption. Figure 13 illustrates relation between compressive strength and split tensile strength of control concrete and concrete mixtures contain wood shavings. The equation of relation between compressive strength and splitting tensile strength of woodcrete is given below, Similar equations were derived by (Siddique et al., 2020; Mohammed et al., 2014).

$$
f_{t}=0.189 f c_{u}^{0.801} R^{2}=0.98
$$

Where:

$f_{t}$ : Split tensile strength $(\mathrm{MPa})$

$f_{c u}$ : Compressive strength for cubic specimens (MPa).

\section{Conclusion}

Some conclusions can be drawn from this study as follows.

The study reveals there is a possibility to produce light weight concrete with up to $15 \%$ wood shavings inclusion with acceptable compressive strength.

The workability decreases as the amount of wood shavings increases which may be attributed to the increase in the internal friction between individual partials in the concrete increased which cause to produce less workable mixtures.
The increase in wood shavings content decreases the weight of concrete mixtures by noticeably decreasing the density of. This might be due the lighter weight of wood shavings compared to conventional fine aggregate and to the produced air voids which is notably obvious in concrete mixtures contain higher wood shavings content.

The absorption of concrete mixtures increases with increase of wood shavings content.

The degradation in the mechanicals properties of woodcrete is obviously increased as the amount of wood shavings increased, however, up $15 \%$ level of replacement concrete mixtures exhibited acceptable compressive strength. Hence, this type of concrete could be used for non structural elements.

Up to $30 \%$ wood shavings concrete mixtures the flexural strength diminishes as the amount of wood shavings increases. At $50 \%$ level of replacement, the flexural strength increases, but, still less than of that of control mix.

\section{Acknowledgement}

The authors would thanks the technicians at Construction Materials Lab at Omar Al-Mukhtar University, for their help and support during the experimental phase of this research.

\section{Funding Information}

The authors would to disclose that the work presented here does not receive any significant financial support.

\section{Author's Contributions}

Ashraf Fadiel: Conducting the experimental program and writing manuscript.

Taher Abu-Lebdeh: Participated in manuscript writing and the analysis of the finding. 


\section{Ethics}

The authors would to disclose that Dr. Taher AbuLebdeh (Co-author) is a member of the editorial board for the American Journal of Engineering and Applied Sciences.

\section{References}

Abu-Lebdeh, T., Fini, E., \& Fadiel, A. (2014). Thermal conductivity of rubberized gypsum board. American Journal of Engineering and Applied Sciences, 7(1), 12-22.

Adesanya, D. A., \& Raheem, A. A. (2009). Development of corn cob ash blended cement. Construction and Building Materials, 23(1), 347-352. doi.org/10.1016/j.conbuildmat.2007.11.013

Ashraf, F. (2015). A review of properties of concrete containing crumb rubber from used tires (In Arabic). 13th Arab Structural Engineering Conference, Algeria December 13-15, 2015.

Bederina, M., Laidoudi, B., Goullieux, A., Khenfer, M. M., Bali, A., \& Quéneudec, M. (2009). Effect of the treatment of wood shavings on the physicomechanical characteristics of wood sand concretes. Construction and Building Materials, 23(3), 13111315. doi.org/10.1016/j.conbuildmat.2008.07.029

Bederina, M., Marmoret, L., Mezreb, K., Khenfer, M. M., Bali, A., \& Quéneudec, M. (2007). Effect of the addition of wood shavings on thermal conductivity of sand concretes: Experimental study and modelling. Construction and Building Materials, 21(3), 662-668. doi.org/10.1016/j.conbuildmat.2005.12.008

Bolden, J., Abu-Lebdeh, T., \& Fini, E. (2013). Utilization of recycled and waste materials in various construction applications. American Journal of Environmental Science, 9(1), 14-24.

Bołtryk, M., \& Pawluczuk, E. (2014). Properties of a lightweight cement composite with an ecological organic filler. Construction and Building Materials, 51, 97-105. doi.org/10.1016/j.conbuildmat.2013.10.065

Daian, G., \& Ozarska, B. (2009). Wood waste management practices and strategies to increase sustainability standards in the Australian wooden furniture manufacturing sector. Journal of Cleaner Production, 17(17), 1594-1602. doi.org/10.1016/j.jclepro.2009.07.008
Fadiel, A. (2013). Use of Crumb Rubber to Improve Thermal Efficiency of Construction Materials (Doctoral dissertation, North Carolina Agricultural and Technical State University).

Fadiel, A., Al Rifaie, F., Abu-Lebdeh, T., \& Fini, E. (2014). Use of crumb rubber to improve thermal efficiency of cement-based materials. American Journal of Engineering and Applied Sciences, 7(1), 1-11.

Koohestani, B., Koubaa, A., Belem, T., Bussière, B., \& Bouzahzah, H. (2016). Experimental investigation of mechanical and microstructural properties of cemented paste backfill containing maple-wood filler. Construction and Building Materials, 121, 222-228. doi.org/10.1016/j.conbuildmat.2016.05.118

Li, M., Khelifa, M., \& El Ganaoui, M. (2017). Mechanical characterization of concrete containing wood shavings as aggregates. International Journal of Sustainable Built Environment, 6(2), 587-596. doi.org/10.1016/j.ijsbe.2017.12.005

Mohammed, B. S., Abdullahi, M., \& Hoong, C. K. (2014). Statistical models for concrete containing wood chipping as partial replacement to fine aggregate. Construction and building materials, $55,13-19$. doi.org/10.1016/j.conbuildmat.2014.01.021

Siddique, R., Singh, M., Mehta, S., \& Belarbi, R. (2020). Utilization of treated saw dust in concrete as partial replacement of natural sand. Journal of Cleaner Production, 261, 121226. doi.org/10.1016/j.jclepro.2020.121226

USEPA. (2021). Wood: Material-Specific Data.

Usman, M., Khan, A. Y., Farooq, S. H., Hanif, A., Tang, S., Khushnood, R. A., \& Rizwan, S. A. (2018). Eco-friendly self-compacting cement pastes incorporating wood waste as cement replacement: A feasibility study. Journal of Cleaner Production, 190, 679-688. doi.org/10.1016/j.jclepro.2018.04.186 